https://doi.org/10.25143/socr.16.2020.1.076-086

\title{
Consumer Rights and Personalised Advertising: Risk of Exploiting Consumer Vulnerabilities
}

\author{
Mg. iur. Zanda Dāvida \\ ORCID: 0000-0002-3173-7078 \\ The University of Latvia, Faculty of Law \\ Zanda.Davida@hotmail.com
}

\begin{abstract}
Have you ever received a frighteningly personalised advertisement with a specific product at the moment when you are thinking about buying that product? Digital technologies have huge positive potential, but their uncontrolled use poses many risks. However, the notion that the current direction of technological development is unavoidable and that the problematic aspects of technology simply need to be tolerated poses a much greater threat to the future. Therefore, this paper discusses one of the risks personalised advertising that seeks to exploit consumer vulnerabilities. Thereby, the aim of the article is to analyse legal problems of targeted and personalised advertising that seeks to exploit consumer vulnerabilities and to propose ways to solve the identified problems. In the article, the author puts forward a thesis (hypothesis) that consumers should be protected from personalised and targeted online advertisements that seek to exploit their vulnerabilities. The hypothesis of the article is confirmed. Therefore, the article identifies four ways that, in the author's opinion, will improve or will provide consumer protection from personalised advertising that seeks to exploit consumer vulnerabilities. In addition, to fully reach the aim of the article, the author analyses the concept of consumer vulnerability. In brief, the article affirms that all of us can be vulnerable in a situation. Therefore, the article applies to all of us.
\end{abstract}

Keywords: personalised advertising, vulnerable consumer, unfair commercial practice. 


\section{Introduction}

Today's digitalisation brings such new technologies in the world common trade market as artificial intelligence, big data, digital tools of data gathering and knowledge generation. Therefore, online advertising is becoming more and more personalised. A chance to reach the exact consumers who might purchase the product is a dream come true for businesses. Consumer profiling is not a new phenomenon, but the scale on which traders can explore consumers now has changed. As consumer behaviour studies have shown, highly personalised and targeted online advertisements influence consumer commercial decision radically more effectively compared to their offline counterparts or general content digital advertisements.

The potential benefits of personalised and targeted online advertisements are appreciated by different subjects - business, consumers, third parties; for example, personalised and targeted online advertisements delivery providers. The potential gain for business is a more effective content of advertisements and distribution of advertisements, as well as a higher chance of concluding a transition with consumers. At the same time, a potentially more relevant content displayed, lower transaction and search costs can be mentioned as potential benefits for the consumer.

Nevertheless, there are losses of consumer decision autonomy, privacy, and other protected legal values, for example, the risk of aggressive advertisement, the risk of discrimination in advertising, the risk of missing out (seeing only the content falling into historically revealed preferences). The author discusses the risk of exploiting consumer vulnerabilities. With the access of artificial intelligence, big data, digital tools of data gathering, knowledge generation and merging it with the insights of consumers behaviour and cognitive studies, businesses understand consumer transactional decision-making better than consumers themselves. This opportunity can promote digital market manipulation, which seeks to exploit consumer weaknesses. Certain forms of nudging or personalised advertising, especially when consumer choice is limited due to trader' monopoly or when the consumer is particularly weak, can be an indicator of unfairness. The artificial agent itself can learn how to exploit consumer vulnerabilities and sensitive information. Therefore, in the author's opinion, exploiting consumer vulnerabilities at the advertising process may result in aggressive commercial practices.

Therefore, the object of the article is the use of technological practice, whose product is targeted and personalised advertisements that seek to exploit consumer vulnerabilities. The aim of the article is to analyse the legal problems of targeted and personalised advertising that seek to exploit consumer vulnerabilities and to propose ways to solve the identified problems. The following general scientific research methods have been used to achieve the aim: grammatical, teleological, systematic, analytical, deductive, and inductive. The research is based on the framework of the European Union consumer law, scientific literature, case law, and studies of market practice. 
In the article, the author puts forward a thesis (hypothesis) that consumers should be protected from personalising and target online advertisements that seek to exploit their vulnerabilities. The article has been concluded with proposals and recommendations of ways how to realise the thesis in the European legal framework and practice.

\section{Personalised Advertising in Context}

The origins of advertising can be traced back to ancient Greece and even in the oldest history of mankind. Traditionally, advertising is understood as any form of announcement or endeavour associated with economic or professional activity, intended to promote the popularity of or demand for goods or services [1, Section 1]; [2, Article 2, point (a)]. Another important feature of advertising is paid content $[22,40]$. The historical development of advertising is closely linked to political and historical processes of each nation state. For example, in Latvia, advertising appeared as a paid service already starting with the recognition of the Latvian state - 100 years ago. However, during the Soviet occupation, there was no competition and free choice in the economy. Consequently, then the meaning of advertising in the territory of Latvia had disappeared [21, 670]. Therefore, one content advertisement can be understood differently by different consumers in different countries. This is one of the reasons why advertisers try to adapt advertisements to the needs of a specific market and now to the needs of an individual consumer.

The will to reach a particular category of consumers by advertisers is called a phenomenon of audience construction in advertising. Draper and Turow argue that it is nothing new and can be traced all the way back to different media, including television, radio, and press [5, 1-23]. In those times personalised advertisements were generally based on segmentation. For example, advertisements for women are speeded at magazines for women, but advertisements for children are displayed on television between cartoons. With digital technological advancement, the searches for methods on how to personalise ads more effectively are on top now. Therefore, at present, we can see how advertising which is based on personalisation takes over or mixes up with advertising which uses the approach of segmentation. Researchers of the European University Institute argue that targeted and personalised advertising is the party that nowadays seems best prepared and where everyone wants to be. Having the ability to reach exactly the consumers who might purchase the product, in a way that they will find most convincing is a dream come true for businesses $[8,48]$. Nowadays advertisers can come very close to individual consumer needs, desires and even fears.

Extensive research can be devoted to discovering the content of the concept of personalised advertising in the digital area because the concepts of personalised advertising are varying by research field, the aim of the study, the author's point of view and technological progress. Without going into the nuances of the concept of personalised advertising, personalisation the context of this paper can be understood as a tailored display of information $[12,1]$, but personalised advertising in the digital area 
is technological practice, made possible by extensive data gathering and knowledge building. Personalised advertising is no doubt changing with the development of digital technologies, therefore strict definition of personalised advertising is not welcome for the content of this paper.

\section{Legal Aspects of Personalised Advertising}

Rott states that this is not new that advertisements are invasive, but personalised advertising feels more invasive because it shows that someone knows more about us than we have meant to tell them $[17,45]$. Information of consumers is required to create and deliver personalised advertising. This information is called consumer data. Organisation for Economic Co-operation and Development (OECD) have made categories of personal data $[14,11]$. They are based on methods how traders collect online data of consumers: 1) requiring consumers to fill an online form (volunteered data), 2) installing cookies in consumers' personal devices (observed data), and 3) using advanced data analytics or machine learning to infer certain consumer characteristics (inferred data). For example, volunteered data is consumer name, phone number, e-mail address, date of birth, address of delivery, responses to surveys, professional occupation, level of education. Observed data - IP address, operating system, past purchases, website visits, speed of click through, user's location, search history, "likes" on a social network, but inferred data is income, health status, risk profile, responsiveness to ads, consumer loyalty, political ideology, behavioural bias, hobbies.

Those examples are not exhaustive, but it must be emphasised that examples of inferred data are the most disturbing and fearing. For example, in a 2013 US Congressional hearing it was stated that data brokers were found to compile lists of consumers using segments such as "rape sufferers" and "AIDS/HIV sufferers" [9]. Inferred data discover sensitive information about the consumer. It makes consumers vulnerable to manipulation because traders know almost everything about the individual consumer. Also, there can be mistakes, because inferred data is based on data analytics or machine learning, inferring certain consumer characteristics. This means that traders can get incorrect data from individual consumers and draw wrong conclusions. It may result in inappropriate or even unfair offers and personalised advertisements. Forbrukerrådet study "Out of Control" shows that even if regular consumers had comprehensive knowledge of technologies and systems driving the AdTech industry, there would still be very limited ways to stop or control data exploitation [7,9]. This means that the consumer can understand that the offers are unfair, yet without the means of affecting it. If a trader has a monopoly position or consumer needs to buy service immediately, this situation may affect consumer economic situation. For example, flight tickets are more expensive than during the regular case.

However, the above-mentioned is not enough to argue that generally personalised advertising is not unfair commercial practice according to the Unfair Commercial 
Practice Directive. On the contrary, personalised advertising is part of technological progress which is neither necessary nor desirable to be stopped. For example, personalised advertising brings a lot of gain for traders: more effective content of ads, more effective distribution of ads and a higher chance of concluding a transaction; it brings gain also for consumers: potentially more relevant content displayed, potentially lower transaction and search costs $[8,49]$. Despite the benefits, personalised advertising as a part of technological progress needs to be controlled. Howells emphasises that advances in technology should not in themselves be an excuse for deregulation [10, 171], especially if it is possible to distinguish significant risks of breach of European Union consumer law and legal principles.

This article puts forward the first thesis that personalised advertising in combination with other circumstances can be recognised as unfair commercial practice. For example, if personalised advertising is based on consumers' discrimination, vulnerability, manipulation or personalised advertising is not transparent or consumer does not have a choice to turn off or select data which he transfers to a trader. Also, in the situation when a trader uses consumers' data, monopoly position can lead to unfair commercial practice. Further in the paper will be analysed the question whether a consumer should be protected from personalised and targeted online advertisements that seek to exploit their vulnerabilities.

\section{What is Consumer Vulnerability?}

European Union consumer law operates with two concepts of consumer: average consumer and vulnerable consumer. Both legal concepts are important, because not all commercial practices may be evaluated from the view of the average consumer. Namely, different commercial practices, and even the same practices in different circumstances, may be found to have different effects depending on the type of consumer they reach or affect $[19,68]$.

Reich and Micklitz explain that vulnerable consumers are those who cannot, or can no longer, cope with the requirements of the modern consumer society. These consumers run the risk of being isolated from social and economic life, be it by over-indebtedness, illness or a lack of possibilities to communicate $[16,46]$. It is important to mention that there are conceptional differences in the European Union consumer law. For example, the Unfair Commercial Practice Directive [3, Recital 18] does not speak of the "vulnerable consumer", but of "consumers whose characteristics make them particularly vulnerable" to unfair commercial practice. However, the practical legal comprehension of consumer vulnerability does not change a lot: consumer vulnerability is referred to any situation in which an individual may be unable to engage effectively in a market and as a result, it at a particularly high risk of getting a poor deal $[18,4]$. The term consumer vulnerability is broad and must be filled with constant in each case per se. Therefore, all of us can be vulnerable in a particular situation. 
The study of United Kingdom Competition and Market Authority distinguishes between two broad categories of consumer vulnerability: 1) market-specific vulnerability which drives from the specific context of particular markets, and can affect a broad range of consumers within those markets; and 2) vulnerability associated with personal characteristics such as physical disability, poor mental health or low incomes, which may result in individuals with those characteristics facing particularly severe, persistent problems across markets $[18,4]$.

In a certain market, all of us can be vulnerable. Therefore, we do not need specific personal characteristics that redirect us from "average consumer", for example, when the consumer purchases in an emotionally stressful situation. A vivid example of this situation is funeral services. The vulnerability can also occur when purchasing a complex service (for example, financial services or purchase of real estate) or if a consumer is required to make a choice when a consumer does not fully understand the options available to him (for instance, services of free electricity market). To be vulnerable associated with personal characteristics consumers need to have, for example, mental health problems, physical disability, being elderly, have low income, lack of time, lack of skills, or confidence to use the Internet, education level. Those examples are not exhaustive. Signs of vulnerability may change; new ones may come. For example, in the legal literature it is stated that "social deprivation" is a growing problem in this context [16, 46], but after economic crises in the European Union has become an actual low-income sign.

One iteration of targeted advertising is known as "emotional targeting", which analyses a person's emotional state based on parameters such as behavior, sentiment analysis, facial recognition, and more, to increase the chances of influencing behavior [6]. Some studies conclude that we are all in a potentially vulnerable position when faced with behavioral targeting because technology is designed to circumvent the defense mechanisms most of us passively employ when we see traditional advertising [7, 47]. Therefore, personalised advertising is closely connected with consumer vulnerability. Nowadays in the marketing strategy it is normal to use personalised advertising that seeks to exploit consumer vulnerabilities, but is it legal?

\section{Legal Aspects of Personalised Advertisements that Seek to Exploit Consumer Vulnerabilities}

From the perspective of consumer protection, unfair commercial practice law is the most appropriate legal instrument which discusses the afore-mentioned problem. Firstly, much personalised advertising is built on vulnerable consumer data and, with this information, it is trying to influence consumer economic decisions. Secondly, in the regulation of unfair commercial practices, consumer autonomy is a core value [13, 83-122]. The rules seek to strike a complicated balance between empowering and encouraging the consumer to take autonomous decisions and protecting consumers from situations in which they are unable to protect themselves, either because they 
are in a position of vulnerability or because of the particular unfairness of the practice [20, 1-18]. Therefore, this article puts forward a second thesis: personalised advertising in combination with technological practice which seeks to exploit consumer vulnerabilities may be recognised as unfair commercial practice according to the Unfair Commercial Practice Directive.

The Directive defines the unfair commercial practice as aggressive when, in its factual context, taking account all of its features and circumstances, by harassment, coercion, including the use of physical force, or undue influence, it significantly impairs or is likely to significantly impair the average consumers' freedom of choice or conduct concerning the product and thereby causes him or is likely to cause him to take a transactional decision that he would not have taken otherwise. The provisions on aggressive commercial practices should cover those practices which significantly impair the consumers' freedom of choice. Those are practices using harassment, coercion, including the use of physical force, and undue influence [3, Recital 16; Article 8]. Even more, some authors argue that it is highly possible that an artificial agent itself learns how to exploit vulnerabilities, from thousands of available data points and without anyone's supervision or direct command, even if its task has been neutrally defined as "display the ad to $\mathrm{X}$ persons with the highest possibility of clicking, at the moment when the chance is the biggest" $[8,60]$. Therefore, the risk of aggressive advertising which is exploiting consumer vulnerabilities is becoming higher with every step of development of digital technology, for example, at present actual artificial intelligence.

Thus, this article puts forward a third thesis - consumers need to be protected from personalised advertising that seeks to exploit consumer vulnerabilities. But the process of personalised advertising is so mysterious and complicated, besides covered by trade secret, that it asks the question of how to fulfil consumer protection into practice.

Firstly, as aggressive commercial practices should cover such practices that significantly impair the consumers' freedom of choice, it is important to start with the empowering of consumer free choice. G20 Consumer Summit Recommendation, 2017 focuses on ten areas to build consumer trust in the digital area. One of them - the consumer should be able to exert control over their personal data and privacy preferences $[15,125$; 128]. Therefore, consumers must be provided with the possibility to choose what data traders collect about them, to change the content and scope of data collection. It should be possible to switch off unwanted personalised advertisements. If a trader does not provide this, it is an essential sign that practice is unfair.

Secondly, the German Supreme Court has stated that if a person does not have access to the information that forms the basis for certain advantages or disadvantages, they cannot contest the way they are being treated. This makes it virtually impossible to control the correctness of the data, contest the sorting into a certain profile, or object to the profile process $[4,70]$. Therefore, without adequate information and understanding, the consumer cannot contest how he was treated developing and addressing him personalised advertisements. Transparent information about personalised advertising is 
essentially important for the consumer. Without this information, neither the consumer nor the supervisory authorities cannot examine a trader's practice of personalised advertising. If a trader does not provide transparent information about personalised advertising, it is an essential sign that practice is unfair.

Thirdly, with how the AdTech industry works today, personal data is being broadcast and spread with few restraints. The multitude of violations of fundamental rights is happening at a rate of billions of times per second, all in the name of profiling and targeting advertising $[7,183]$. Everyone understands that broadcasting and spreading of personal data is out of control, despite there being European Union regulation (Data and Consumer Protection law) that finds it illegal. The Forbrukerrådet's study argues that advertisers and publishers need to look toward alternative digital advertising methods that respect fundamental rights [7, 7]. Political, legal, and technological debates need to be launched on the need to change existing illegal practices. Comprehensive data collection and sharing must be stopped, otherwise, such practice is an essential sign that it is unfair. Besides, this practice violates data protection laws.

Fourth, with the widespread development and use of personalised advertising, the market power of personalised advertising service providers inevitably increases, and large data concentration or data monopoly is formed. If a trader uses this monopoly for creating and offering personalised advertising, it makes a high risk of aggressive advertising. Mak argues that concentration of consumer data in the hands of one trader can be solved not only by "classical" consumer protection law but also by competition law [11, 274]. Therefore, the supervisory authorities have legal weapons for combating personalised advertising that seeks to exploit consumer vulnerabilities, which is determined by using consumer data monopoly. But the questions for the next study remain - why supervisory authorities remain afraid to do this and what can be done to solve this problem of inertia.

\section{Conclusion}

1. Generally, personalised advertising is not an unfair commercial practice according to the Unfair Commercial Practice Directive. On the contrary, personalised advertising is part of technological progress, which is neither necessary nor desirable to be stopped. However, it must be emphasised that despite the benefits of personalised advertising, this process has a high risk that needs to be controlled.

2. Personalised advertising in combination with other circumstances can be recognised as an unfair commercial practice. For example, if personalised advertising is based on consumer discrimination, vulnerability, manipulation or personalised advertising is not transparent or consumer does not have a choice to turn off or select data which he transfers to a trader. Also, in the situation when a trader at personalised advertising uses a consumer data monopoly position can lead to unfair commercial practice. 
3. This article is analysing legal aspects of personalised advertising that seeks to exploit consumer vulnerabilities. The hypothesis of the article is confirmed. Namely, consumers need to be protected from personalised advertising that seeks to exploit consumer vulnerabilities.

4. The article identifies four ways that will improve or will provide consumer protection from personalised advertising that seeks to exploit consumer vulnerabilities.

5. Consumers must be provided with the possibility to choose what data traders collect about them, to change the content and scope of data collection. It should be possible to switch off unwanted personalised advertisements. If a trader does not provide this, it is an essential sign that such practice is unfair.

6. Without transparent information about personalised advertising, neither the consumer nor the supervisory authorities can examine a trader's practice of personalised advertising. If a trader does not provide transparent information about personalised advertising, it is an essential sign that the practice is unfair.

7. Advertisers and publishers need to look toward alternative digital advertising methods that do not use comprehensive data collection and sharing. It must be stopped, otherwise, such practice is an essential sign that it is unfair.

8. With the widespread development and use of personalised advertising, the market power of personalised advertising service providers inevitably increases, and large data concentration or data monopoly is formed. If a trader uses this monopoly for creating and offering personalised advertising, it makes a high risk of aggressive advertising.

9. The supervisory authorities have legal weapons for combating personalised advertising that seeks to exploit consumer vulnerabilities, but the questions for the next study remain - why supervisory authorities are afraid to do this and what can be done to solve this problem of inertia.

\section{Patērētāju tiesības un personalizētās reklāmas: patērētāju ievainojamības izmantošanas risks}

\section{Kopsavilkums}

Vai Jūs kādreiz esat saṇēmis biedējoši personalizētas reklāmas ar konkrētu preču vai pakalpojumu piedāvājumiem tieši tajā brīdī, kad Jūs domājat par šīs preces vai pakalpojuma iegādi? Digitālajām tehnologiijām ir liels pozitīvs potenciāls, bet vienlaikus tās rada daudzus to nekontrolējamas izmantošanas riskus. Tomēr daudz lielākus draudus nākotnei rada uzskats, ka pašreizējais tehnologiju attīstības virziens ir neizbēgams un ka tehnolog̣iju lietošanas negatīvās blaknes ir vienkārši jāpieṇem. Šì raksta ietvaros tiek 
analizēts viens no šiem riskiem, proti, tehnologiskā prakse attiecībā uz personalizētajām reklāmām, kuras balstās vai ir tendētas uz patēēēāja mazaizsargātības (ievainojamības) izmantošanu, kā arī analizēta šìs prakses tiesiskā problemātika un piedāvāti identificēto problēmu risinājumi. Rakstā tiek izvirzìta hipotēze, ka patērētāji ir jāaizsargā no šādām personalizētām reklāmām, un piedāvāti četri tiesību izpratnes veidi, kas varētu uzlabot patērētāju tiesību aizsardzību no tām. Lai pilnībā atklātu raksta mērḳi, papildus tiek analizēts patērētāja mazaizsargātības koncepts, savukārt secinājumos apstiprināts, ka mēs visi varam būt mazaizsargāti kādā konkrētā situācijā. Lìdz ar to šis raksts ir aktuāls mums visiem.

Atslēgvārdi: personalizētā reklāma, mazaizsargāts patērētājs, negodīga komercprakse.

\section{References}

1. Advertising law. Adopted at 20.12.1999. Law of the Republic of Latvia. Latvijas Vèstnesis 7, 10.01.2000. Entered into force 24.01.2000. Available: https://likumi.lv/ta/en/en/id/163-advertising-law.

2. Directive 2006/114/EC of the European Parliament and of the Council of 12 December 2006 concerning misleading and comparative advertising. OJ L 376, 27.12.2006. Available: https:// eur-lex.europa.eu/legal-content/EN/ALL/?uri=celex:32006L0114.

3. Directive 2005/29/EC of the European Parliament and of the Council of 11 May 2005 concerning unfair business-to-consumer commercial practices in the internal market and amending Council Directive 84/450/EEC, Directives 97/7/EC, 98/27/EC and 2002/65/EC of the European Parliament and of the Council and Regulation (EC) No 2006/2004 of the European Parliament and of the Council. OJ L149/22, 2005.

4. Domurath I. (2019). Technological totalitarianism: Data, Consumer Profiling, and the Law. In L. de Almeida, M. C. Gamito, M. Durovic and K. P. Purnhagen (edited by). The Transformation of Economic Law. Essays in Honour of Hans-W. Micklitz. London.

5. Draper N. A., Turow J. (2017). Audience Constructions, Reputations, and Emerging Media Technologies: New Issues of Legal and Social Policy. In The Oxford Handbook of Law, Regulation and Technology. R. Brownsword, E. Scotford \& K. Yeung (Eds). Oxford University Press.

6. Emotional and Sentiment Targeting. ADmantX. Available: https://www.admantx.com/ emotional-and-sentiment-targeting/.

7. Forbrukerrådet study Out of Control. How consumers are exploited by online advertising industry. (2020). Available: https:/fil.forbrukerradet.no/wp-content/uploads/2020/01/2020-01-14-out-ofcontrol-final-version.pdf.

8. Jabłonowska A., Kuziemski M., Nowak A. M., Micklitz H.-W., Pałka P., Sartor G. (2018). Consumer Law and Artificial Intelligence Challenges to the EU Consumer Law and Policy Stemming from the Business' Use of Artificial Intelligence. Final report of the ARTSY project, EUI Working Paper LAW 2018/11, Italy.

9. Hill K. (2013). Data Broker Was Selling Lists of Rape Victims, Alcoholics, and "Erectile Dysfunction Sufferers". Available: https://www.forbes.com/sites/kashmirhill/2013/12/19/ databroker-was-selling-lists-of-rape-alcoholism-and-erectile-dysfunction-sufferers/. 
10. Howells G. (2020). Protecting Consumer Protection Values in the Fourth Industrial Revolution. Journal of Consumer Policy, 43.

11. Mak V. (2018). Gedachten bij een gepersonaliseerd consumentenrecht (Eng. Thoughts on a personalised consumer right). Tijdschrift voor consumentenrecht E handelspraktijken, 6.

12. Mik E. (2016). The erosion of autonomy in online consumer transactions. Law, Innovation and Technology, 8(1).

13. Micklitz, H. W. (2006). The general clause on unfair practices. In G. Howells, H. W. Micklitz and T. Wilhelmsson (Eds.). European fair trading law: The unfair commercial practices directive. London: Routledge.

14. OECD. (2018). Background Note by the Secretariat, Personalised Pricing in the Digital Era. DAF/COMP 13. Available: https://one.oecd.org/document/DAF/COMP(2018)13/en/pdf.

15. Riefa C. (2017). G20 Consumer Summit on building a digital world consumers can trust. EuCML, 3.

16. Reich N., Micklitz H.-W., Rott P., Tonner K. (2014). European Consumer Law. 2nd edition. Cambridge: Intersentia.

17. Rott P. A. (2019). Consumer Perspective on Algorithms. In The Transformation of Economic Law: Essays in Honour of Hans-W. Micklitz. L. de Almeida, M. C. Gamito, M. Durovic and K. P. Purnhagen (edited by). London.

18. United Kingdom Competition and Market Authority. (February 2019). Consumer vulnerability: challenges and potential solutions. Available: https:/www.gov.uk/government/publications/ consumer-vulnerability-challenges-and-potential-solutions/consumer-vulnerability-challengesand-potential-solutions\#foreword-by-the-chairman.

19. United Kingdom Office of Fair Trading. (May 2008). Guidance on the UK Regulations Implementing the Unfair Commercial Practices Directive. Available: https://assets.publishing. service.gov.uk/government/uploads/system/uploads/attachment_data/file/284442/oft1008.pdf.

20. Van Boom W. H., Garde A., Akseli O. (2014). Introduction to 'the unfair commercial practices directive'. In W. H. Van Boom, A. Garde, and O. Akseli (Eds.). The unfair commercial practices directive: Impact, enforcement strategies and national legal systems. Farnham: Ashgate.

21. Latvija: Nacionālā enciklopēdija (2018). (Eng. Latvia. National Encyclopaedia). Rīga: Latvijas Nacionālā bibliotēka.

22. Svešvārdu vārdnīca: 25000 vārdu un terminu. (2008). (Eng. Dictionary of foreign words. 25,000 words and terms). Sastādītāji: I. Andersone, I. Čerṇevska, I. Kalniṇa, D. Nātriṇa, R. Puriṇa, L. Vjatere. Rīga: Avots. 